Article

\title{
The Institutional Context of 'Linguistic Injustice': Norwegian Social Scientists and Situated Multilingualism
}

\author{
Lynn P. Nygaard \\ Peace Research Institute Oslo (PRIO), P.O. Box 9229 Grønland, 0134 Oslo, Norway; lynn@prio.org
}

Received: 23 November 2018; Accepted: 28 January 2019; Published: 1 February 2019

check for updates

\begin{abstract}
The debate about 'linguistic injustice' centers on whether or not English as an additional language (EAL) writers face challenges in writing academically that are qualitatively different from those of novice academic writers irrespective of language background. This study aims to add nuance to this debate by looking at range of writers (from novice to expert) within an interdisciplinary social science research institute in Norway in order to investigate the mediating role of the institutional context. Using an ethnographic approach with an academic literacies perspective, it examines the challenges these writers face and discusses them in light of tensions between identity and institutional environment. It argues that the high degree of immersion in English causes 'situated multilingualism', where their ability to write about their topic in English surpasses their ability to write about it in Norwegian. Nonetheless, even the expert writers, particularly those in disciplines that value a unique authorial voice, demonstrated insecurity and lack of ownership to their writing in English. Moreover, the pressure to also sometimes write in Norwegian represented an additional site of negotiation not faced by their non-Norwegian counterparts. This suggests that the challenges EAL writers face are not determined by their language background alone, but also by their institutional environment-including the pressure to publish 'internationally', the amount of writing expected, and their immersion in English.
\end{abstract}

Keywords: English as an additional language (EAL); academic literacies; academic writing; research productivity; English for Research Publication Purposes (ERPP); multilingualism

\section{Introduction}

Although English is not the most common first language for most academics, it is perhaps the most common second language and is generally (although not uncontroversially) considered the lingua franca of academic publishing see, e.g., [1,2]. This means that most publishing academics are probably publishing in a language that is not their native tongue.

Amongst both academics and practitioners, there is considerable debate about whether having English as an additional language (EAL) puts scholars at a disadvantage compared to those who were raised using English as their main language. Some, on the one hand, argue that EAL scholars face significant challenges expressing themselves, developing a sufficiently flexible vocabulary, and writing a convincing argument [3-8]. This may result in not using language exactly as a native speaker would e.g., $[8,9]$. Having these differences in language use pointed out by reviewers may not only result in a feeling of having one's academic identity challenged [10], but also hinder publication [11-13].

On the other hand, many others argue that distinguishing between EAL speakers and those who have English as a first language oversimplifies the problem [14-16]. These authors suggest that not all EAL writers experience academic writing in the same way. For example, academics in Scandinavia seem to struggle less than academics in, e.g., Asian countries [17]. More important, the 
challenges they seem to face do not seem to be qualitatively different than those faced by writers with English as a first language. They argue that because academic English is so different from everyday English, the biggest writing challenges appear in the transition from novice to expert, when writers are developing a specific academic language and voice $[16,18]$. Evidence from the research productivity literature supports the assertion that the most productive academics are the highest ranked, and thus established experts $[19,20]$. Although it stands to reason that developing expertise in both subject matter and writing would make academic publication less problematic, what has made this position so controversial is the conclusion that Hyland [16] in particular seems to draw: that because no one has 'academic English' as a first language, then the issue of native language is inconsequential. He goes so far as to say that 'linguistic injustice' can thus be described as a myth [16].

While considerable evidence exists that EAL writers may have a more difficult time getting their work accepted in journals [11-13,21-23], it is difficult to tell from the quantitative literature on research productivity whether or not the real or perceived challenges EAL writers face actually hinder their overall productivity compared to those with English as a first language. Cross-national studies indicate that working conditions and productivity vary between countries [24,25], but native language is seldom examined as a separate variable. One exception is a study by Mamiseishvili and Rosser [26], which found that international faculty at a US university were actually more productive than their US counterparts. Mamiseishvili and Rosser suggest that at least one reason why this might be so is that the international faculty felt uncomfortable in their teaching roles because of their language, and thus felt more comfortable in a writing context-where presumably 'accent' was less of a hindrance, but also they might have access to language brokers [27]. The productivity of international faculty is probably also likely to be related to proficiency in English being a prerequisite for mobility in the first place [28] — which could provide additional evidence for the argument that the primary challenge of academic writers is to transition from novice to expert. Interestingly, in a study on 'top-producing academics' in Europe, those who produce the most are not only experts (i.e., have reached professorship), but they regularly publish 'in a foreign language' - which presumably also means that top producers from English-speaking countries regularly produce in languages other than English [20].

Another factor that could affect apparent proficiency in English is the discipline to which the EAL writer belongs. While the research productivity literature has examined how productivity varies by discipline [29], there has been little inquiry into the link between discipline and language. However, other literatures in the field of linguistics have demonstrated that some disciplines favor 'text modules' (e.g., natural sciences) and others 'theoretical subtleties' (e.g., qualitative social sciences and humanities), and that disciplinary culture determines what is considered good writing $[8,30,31]$. One could expect that developing a unique authorial voice with 'theoretical subtleties' would be more difficult for an EAL researcher than writing in a field where the unique authorial voice is valued less than consistent terminology.

What has not been systematically examined in this debate is the role of the institutional environment in shaping not only proficiency in English but also the nature of the challenges faced by EAL writers. Blommaert et al. [32] use an ethnographic approach and look at how individual speakers are able to communicate in a multilingual context. They argue that 'multilingualism is not what individuals have or lack, but what the environment, as structured determination and interactional emergence, enables and disables them to deploy' [32]. They argue that individuals in a multilingual context can develop what they call 'truncated multilingualism', that is, competence in an additional language that is restricted to a particular subject matter and does not extend to increased language ability as a whole [32]. Although not specifically stated, their assumption seems to be that in certain contexts, their ability to communicate in a second language may (almost) equal their ability to communicate in their first language; they do not explore how their ability to communicate in their first language - within that same context—-might be affected by the same environmental forces that allow them to develop such proficiency in a second language. 
These different directions in the literature all seem to suggest that it is difficult to generalize about the experiences of EAL writers as a homogenous group, and that context should matter. In other words, the challenges facing EAL researchers seem to be not simply a function of only the language they grew up speaking, but also the expectations placed upon them in their everyday institutional environments and experience of reading and writing about research.

Academic literacies theory provides a fruitful framework for critically examining how EAL writers in a particular context experience publishing in English. As a close relation to New Literacy Studies, the academic literacies perspective directs the researcher's gaze to how writing is a social practice situated in a specific context for a specific purpose [33-35]. Viewing writing as a social practice means acknowledging that the writer is not only grappling with the intellectual and linguistic exercise of converting ideas to text—of finding the right words and syntax-but also negotiating the demands of their perceived institutional environment and various aspects of identity [36-38]. Moreover, researchers participate in multiple institutional environments at the same time, each with their own expectations about what constitute good writing or acceptable academic output. At the departmental level, for example, researchers might be expected to produce not only academic articles published in English, but also materials aimed at students in a local language. At the national level, researchers may be encouraged to publish in their local languages, but perhaps when they attempt to seek academic positions outside their own country, only their publications in English might be taken into account [11,39]. These conflicting expectations can create sites of negotiation [38] where the researcher struggles to understand not only what is 'correct', but also what is expected and what they themselves prefer. Looking closely at a specific institutional setting through an academic literacies lens can help answer the question of what factors might make EAL writers-even within the same language group-different from one another.

The issue addressed here is, in the debate about linguistic injustice, whether and to what extent it may be possible to acknowledge that both 'sides' can be right: that while the biggest writing challenges might be related to being a novice academic writer, writing in English as an additional language brings an extra dimension of difficulty to something that was already difficult to begin with. More importantly, this paper addresses the issue of whether or not it is possible to treat EAL writers-even within the same language group—as a homogenous group without taking into account their institutional environments.

The specific question asked in this paper is how individual writers within the same institutional setting experience the challenge of writing in English as an additional language, and how these challenges are related to the multiple environments (both outside the institute and subgroups within the institute) to which they belong and identify with. The study is conducted at an interdisciplinary Norwegian social science research institute where English is the dominant language for both reading and writing. Specifically, I aim to identify sites of negotiation related to choice of language for publication, and challenges related to writing in the target language. I find that while the participants identify challenges related to developing their own voice in English, they unanimously agree that the challenges of writing in Norwegian are even greater largely because of the 'situated multilingualism' that results from having engaged in the subject matter exclusively in English. Their ability to write about their research in English not only exceeds their ability to write about other topics in English ('truncated multilingualism'), but also their ability to write about their topics in Norwegian. Despite this proficiency, they nevertheless face specific sites of negotiation related to identity and language choice that are not experienced by native speakers of English.

The findings in this study thus serve to add nuance to the debate about 'linguistic injustice' by looking not only at native language, but also at the role of identity and the institutional environment. It further adds to the literature on multilingualism by suggesting that institutional environment affects the development of both the first language and additional languages, including leading to a situation of 'situated multilingualism', where fluency in an additional language may surpass fluency in a first language for a particular subject area. 


\section{Methods}

As is common with academic literacies research, this article takes an ethnographic approach [40-42] in the sense that it looks beyond issues of language and at how individual researchers understand their identity as researchers and the expectations of their different environments for a deeper understanding of the challenges they face when writing in English. As such it aims for ethnographic depth rather than statistical generalizability [42].

The institute investigated in this study is part of Norway's research institute sector, which means that it does not engage directly in teaching (although individual staff members may be associated with universities), and it focuses exclusively on producing (externally funded) research. It has a research staff of about 60 full-time equivalent researchers, mostly based in the social sciences, but also some from the humanities. This paper reports on a specific aspect of a more general study carried out at the institute where I conducted semi-structured interviews covering a wide range of themes related to academic writing and publishing. The focus of the main study was not on language, but rather on issues related to genre, co-authoring, selection of journals, and prioritization of writing [38]. However, the issue of language came up often enough that I felt it would be useful to analyse separately, and is thus reported on here.

The group of informants comprised about one third of the staff members (19 informants, 16 of which were EAL writers), roughly matching the institute's composition with respect to age, gender, methodological orientation, and language background. Interviews were voluntary and based on the principles of informed consent and confidentiality. Each interview lasted about $90 \mathrm{~min}$, and participants were given the option of carrying out the interview in either Norwegian or English, but all opted to conduct the interview in English. All names used here are pseudonyms.

The interview involved 'talking around text' [43], where the informants brought in one text they were satisfied with and one they were not satisfied with as a way to talk about what kinds of things they find satisfying, fulfilling, or meaningful about academic writing, as well as what kinds of things they find frustrating, difficult, or pointless. In the second part of the interview, I asked informants to talk me through the entire research and writing process-from getting an idea, to securing funding, carrying out research, writing various drafts, and finally publishing. The purpose of these interviews was to not take for granted how the writing process is experienced, but to rather problematize and tease out various aspects of the subjective experience, including how the institutional environment is perceived and how they think of themselves as writers. The interviews were transcribed and coded using NVivo. After the interview, to help triangulate interview responses and compare across groups (gender, discipline, language background, etc.), participants were asked to fill out a short questionnaire (mostly Likert-scale statements) that covered some of the main topics from the interview guide. In this analysis, I look specifically at the transcript sections and survey responses that specifically mentioned language, and focus largely on those who have English as an additional language. I also make a point of comparing responses from those with a more quantitative methodological orientation to those who have a more qualitative or humanities orientation.

\section{Institutional Setting and the Pressure to Write in English}

The research institute in this study is located in Oslo, Norway. At the national level, the pressure on academics in Norway to have a voice in the international discourse is augmented by the fact that Norwegian is a small language (roughly 5 million native speakers in total). The necessity of publishing in English is thus almost taken for granted [1]. Nevertheless, there is also a counter pressure to keep Norwegian alive as a language in which academics not only sum up findings that have been published in English, but also as a language in which original ideas are expressed [1]. This is often expressed in a push for 'parallel linguistic competence,' a strategy common to all Nordic countries $[17,44]$. What this means in practice, however, is that academic output is published in English, while outreach publications are in Scandinavian languages [45]. 
This dilemma-acknowledging the importance of publishing in English yet wanting to keep Norwegian alive as a language for academic discourse-is evident in Norway's bibliometric scheme for distributing funding to research-producing settings. Unlike many other bibliometric systems, Norway's scheme does capture non-English output [39]. However, additional points are given to publications that appear in top-tier journals and presses, and the main criterion for inclusion in the top-tier is 'international,' which in effect means 'English language' [1]. This means that those institutes that publish in English stand to gain more financially [39].

At the institutional level for the specific institute in this study, there is an additional pressure to publish in English because the subject matter that is the thematic focus of the institute is inherently international: international politics and relations between countries. The institute also hosts two top-ranked journals in the field of international relations, and both journals are English language.

Daily activities center around competition to get funding, carrying out research, and disseminating research findings to both the academic community and a broader public, as well as specific stakeholders (such as policymakers). Although researchers are expected to target not only academics but also stakeholders and the general public, only academic output is explicitly measured and rewarded. Perhaps as a result, most output is academic in nature. Virtually all this academic output is in English. Even projects funded by Norwegian ministries require deliverables in English, regardless of whether these deliverables are reports that will be used for policy input and not published internationally. Given the international nature of the particular discourses in which the institute's researchers engage, this is perhaps not surprising.

The international identity of the institute is also reflected in the language used internally: All official written material about the institute is in English (including strategy documents, annual reports, websites, etc.), and all official meetings take place in English. It is institutional policy to make the institute a place where researchers from all over the world can come for shorter or longer periods and be made to feel like they can participate in institutional life on equal footing with everyone else. About one-fourth of the research staff is non-Norwegian (most with English as a native language).

The focus on English in virtually every conceivable setting at the institute means that Norwegian staff members are (or become) generally more proficient in English than many other Norwegian academics. The question here is whether (and to what extent) this proficiency reduces many of the common constraints faced by EAL researchers-and to what extent it might create new ones.

\section{Writing in English: Limits of Second Language Proficiency}

Not surprisingly, most of my 16 EAL informants talked about writing in English as being a challenge, although few would admit to it being a significant constraint. Indeed, most described themselves as very fluent in English. Only two EAL writers responded to the questionnaire statement 'I feel confident writing in English' with 'disagree'; 12 responded 'agree' and 2 answered 'strongly agree.' As Anne points out, 'I don't think about that so much. I'm so used to it that it's okay.' While they do not feel it hinders their overall productivity, several said that at times finding the right words makes the writing process more difficult. Nora says:

Some days, that is enough to kind of stop the whole writing process ... Other days you just find a temporary word and you know that you'll go back and then polish it later... It doesn't stop the reflection process ...

Although writing in English seemed to have little impact on their overall ability to get words on paper, it did seem to affect their perceived competence in writing and their conception of voice. Similar to what was reported by Ingvarsdóttir and Arnbjörnsdótir [8], the most common complaint was that they felt it made them less creative with language: drier, more formal and fewer metaphors. While those with English as a first language seem more concerned about 'authorial voice'-'playing with the language' and challenging the conventions of the genre-most of the EAL writers were concerned about 'getting it right.' Frida explains, 'I feel like I just don't know the English language 
well enough,' and says that she can spend hours Googling words and grammar rules, ending up even more confused.

Part of 'getting it right' involves putting together familiar strands of words, or lexical bundles [9]. Hans elaborated that writing in English is a bit like putting together building blocks—reassembling strings of words that he has heard before:

I learned the vocabulary... And it seems logical. But I'm not really confronted with ... what I'm saying as I would if I were using my everyday Norwegian language. ... So it's a bit like a technical medical language ... where you can kind of just learn what the paradigm is and what the building blocks are, and then you can build something nice with it. And [at least in my discipline], that's not really how it's supposed to be.

The discomfort Hans feels about using English as building blocks, however, is also related to being situated in the humanities, which values the unique voice over the instrumental use of ready-made lexical bundles [30].

Less creativity with language also means that the writing becomes less personal in English than it is in Norwegian for most of these researchers, almost regardless of how expert they are or how much English they write. Erik admits:

Ninety-five percent of everything I write is written in English. That is not my native language and is never going to be. I guess the older I get, the more I become aware that it is a significant limitation. It's hard to develop ... a personal language in a language which is not your own. ... You are not at all good with the nuances, with the finer nuances, of the language that you are operating in.

Erik's comment illustrates the high standards and ambitions for his own writing, and the frustration he feels by his inability to master nuance at the level of not just a native speaker, but a very adept writer. This reflects what Olsson and Sheridan [17] find with Swedish academics: they are proficient enough to be aware of nuances in English, although they do not necessarily feel they are able to master them.

The pressure to 'get it right' also influences how they interact both with native-English speaking co-authors and with language editors. Several described feeling somewhat insecure about being 'wrong,' and being quick to assume that the native English speaker would always be 'right', making it difficult for them to challenge or disagree. Recalling an experience with an American co-author, Frida says:

We had a sentence that I didn't like, and she wanted me to explain why I didn't like it. I said I just-that word is too strong. And she's like 'Too strong?' ... It's quite likely that I'm way too stressed. But it's also the feeling of not having the language in my blood, not really knowing ... the strength, the value of a particular word.

Here, Frida reacted to a word that in her mind made a claim stronger than she felt was warranted, but her American co-author disagreed. Frida felt that not having the 'language in her blood' made it difficult to disagree with her co-author, and thus capitulated. I also observed that both she and other EAL writers were too quick to assume that language-related edits made by professional English-language copyeditors were 'correct,' only later to discover that their original text was accepted usage within their field. Because they identify as 'second-language speakers,' they seem to feel they lack the ammunition to challenge a native speaker on points of language. It is difficult for them to ascertain whether a correction is made because their original wording breaks a grammatical rule, challenges a stylistic convention, or simply 'sounds wrong' to the editor. Even the most expert authors seem to display a degree of uncertainty when working with a second language that makes them perhaps too quick to doubt their authorial instincts. 


\section{Strategies for Coping}

Most of those I interviewed had a pragmatic view about getting help on language: they may feel that they are at a linguistic disadvantage but can take steps to compensate. 'It's like running with a sprint leg, you know?' says Kyrre, when he explained to me what it was like to write in English. 'Like handicapped people ... running with blades instead of a leg.' The primary strategy for compensating was simply to get language editing assistance through what Lillis and Curry call 'literacy brokers' [27]. When I asked him whether having his work edited by a language editor challenged his sense of ownership to his own work, Kyrre explained, 'it's more about pride and ego than it is about being challenged. I just need to set [language editing] up and hope that I have a budget for it.' Describing one concrete experience with a language editor, he said that even though the editor made a large number of changes, he still felt like the work was his own; in his mind, the editor simply helped level the playing field. He admitted, however, that he would have more problems with language intervention in Norwegian: 'I probably would have felt like I would have lost some ownership if it was in Norwegian.' Kyrre's pragmatic approach to receiving language assistance, coupled with his feeling of not losing ownership despite heavy editing, suggests that as a point of departure he feels less ownership to what he writes in English compared to what he writes in Norwegian.

The pragmatic approach to language editing was reflected by many of the other participants. Several others also talked about using the input from a language editor to learn, regardless of how proficient or experienced they are in publishing in English. Erik says, 'I actually try to spend some time on the comments I get back rather than just go through and accept. You'll find that there's a lot to learn from it.' Likewise, Harald talked about how, instead of simply typing in the handwritten comments from the editor, he would examine each comment carefully and attempted to learn from them in ways that could extend beyond the immediate project. Harald seemed to be using a literacy broker to not just improve his English, but also to become a better writer, and suggests that identifying as a 'language learner' becomes a more generalized perspective that extends to other aspects of writing beyond those strictly related to issues of 'correctness'. Although the native English speakers in my group of participants also report spending a significant time revising language as well as content, they did not, however, seem to conceptualize it as learning or identify as learners.

Identifying as learners for some also meant consciously engaging in other practices that would position them to learn. Similar to the Spanish researchers described by Pérez-Llatada, Plo, and Ferguson [6], several of my participants talked about actively exposing themselves to English through reading. For example, Erik pointed out that he tries to read 'good writing' in English, particularly fiction: 'I'm somebody who reads an awful lot of awful English. Lots of reports and stuff like that-[which] are designed to undermine your language skills.' While the native English speakers I spoke with also talked about the importance of reading, they did not seem to think of it as having a function for language learning or speak about choosing specific texts for the sole purpose of improving their language.

Karoline looks at more than just language when she looks for role models in reading:

Often I go back to articles that I thought were good and try to see what do they actually do here, like

for an abstract... Why was that abstract appealing and then I try and read it and think, okay maybe

I can steal an idea from how they did it.

Karoline's comment points to a larger challenge that many of my informants pointed out: it wasn't writing in English that they felt was particularly difficult, but writing at all. Several claimed that the native English speakers had an easier time writing not necessarily because of their language skill, but because they had more practice. Almost all participants-Norwegians and non-Norwegians-spoke of a significant difference between the way writing is taught in Norway and English-speaking countries: they all agreed that Norwegian students write much less. For example, in their undergraduate studies Frida (who was educated in Norway) says she wrote about three papers per year, while David (who was educated in an English-speaking country) claims to have written about thirty. The Norwegian 
participants who spent part of their education in English-speaking countries claim that the experience changed them as writers mainly because of the sheer volume of writing they were expected to produce. This suggests that the institutional environment can have an influence on proficiency not just with respect to language, but also with respect to becoming a writer in a more general sense.

\section{Situated Identities and Sites of Negotiation}

As a research environment that attracts researchers from all over the world and focuses on a subject matter that is inherently international, the institute differs from other social science research environments that focus on phenomena of local interest (social welfare, education, urban planning, and so on). This unusual setting creates highly situated sites of negotiation and challenges common assumptions about who second-language writers are, and the nature of second-language writing.

The literature on EAL writing suggests (albeit implicitly) that classifying a person's first, second, or third language is straightforward. However, even in my relatively small sample of 19 , there were four people who could not be easily classified-because they moved from one country to another while they were still young, because they have parents who speak different languages, or because they spent a significant part of their education in another country. As a result, their own conceptualization of their first language is fluid and depends on whether they are writing or speaking, or whether they are writing academically or to a wider audience. For example, when asked what her native language is, Karoline said English for writing, but Norwegian in general-although another European language was the one she spoke first. She connects language with a particular genre or setting: English for academic writing, Norwegian for writing for a children's magazine, and the third European language for talking with family and friends. In describing her struggle to write in her 'mother tongue' (the European language she spoke first), she says:

I guess it's hard to find the right academic way of writing and I've been reading a lot of [European language] articles on [my topic] to copy how they write. I mean, I know how to write grammatically correctly, and I know how to speak correctly, but that's mainly talking about dinner or how your day was - not theoretical concepts and that kind of thing. So one of the comments I had was it was-I don't know the word in English - but it was made into English, sort of anglofied. The language, even though it was correct (... ) just was a bit off because it seemed like I was thinking in English, which is probably what I was doing ...

As for Norwegian, which is the language she uses most often on an everyday basis outside of work, she says that she uses it mainly for popular writing rather than academic writing. 'I haven't really written an academic article in Norwegian ever,' she says.

Even for those whose linguistic identity was less ambiguous, the pattern of writing in English for academic output and in Norwegian for general audiences is widespread throughout the institute. Indeed, the same pattern is found throughout Scandinavia [45].

Perhaps the most striking finding in this study is that reading and writing academically exclusively in English seems to have resulted in a situation where the researchers report that, despite the challenges of writing in English, it is actually more difficult for them to write in Norwegian because they simply lack the vocabulary. In other words, when the input language has been almost exclusively English, writing in any other language becomes difficult. For example, Erik explains that

You read about [technical terms] in English, and you've written about them in English, and there's no reason you should have the Norwegian language to talk about them, unless you taught them to students in Norwegian, or something.

The difficulty of writing in Norwegian about their research also means that translation, an important coping strategy used by other European EAL writers see, e.g., [6], is considered irrelevant by my informants; none felt that it would be easier to write in Norwegian first and then get it professionally translated into English, especially if they work with a highly specialized discourse. 
Writing in Norwegian to the general public was even described by some as a 'double-translation': not only shifting from English to Norwegian, but also from speaking to an academic audience to the general public-a shift that not everyone finds equally straightforward.

When the difficulty of writing in Norwegian for the general public is coupled with an expectation that it should be easier than writing for an academic audience in English, the result can be frustration and despair. Frida explains:

I haven't written in Norwegian for a long time. And once I tried, I gave it up because it was too difficult ... I felt I didn't have the words in Norwegian that I needed ... It's the same feeling I have when I meet someone and they ask me what I do and I'm supposed to explain my research to them ... But that's sad... I believe in that obligation to bring my research also out to a Norwegian audience. But ... it's hard not being able to write well in Norwegian. ... As my mother tells me, it's what I should be good at.

For Frida, making the choice to write something in Norwegian thus entails a negotiation between her identity as a socially-engaged researcher who is morally obligated to participate in the public debate, and her identity as an 'academic,' who should focus primarily on journal articles (in English-language journals). In other words, she has to pit concerns about individual career trajectory against larger social concerns.

For Marit the decision to write in Norwegian on occasion has to do with challenging herself as a writer:

I think we should also sometimes try to write about things in Norwegian to get closer to the topic. Because sometimes it can be quite revealing ... That's when you realize if you have really understood some things ... If you're not able to explain it in your mother tongue, then there is a problem there, I suppose. Have you really understood it?

Writing in Norwegian forces Marit to engage with her material in a way that writing in English does not. She claims it tests her knowledge by requiring her to choose alternative ways to explain things, and makes her a better scholar.

The decision for the researchers to write in Norwegian, whether to fulfil the obligations of a socially-engaged researcher or to get closer to the material, is one that native English speakers at the institute seldom, if ever, face. Thus, the EAL writers not only face a more difficult task writing, largely because they perhaps feel more distant from the text than their English-language counterparts and question their own competence to a greater degree, but also because they face additional sites of negotiation-where deciding to write in a language other than English can represent a negotiation between environmental pressures and individual identity.

\section{Discussion and Conclusions}

Kyrre's metaphor of 'running with blades' suggests that even the most proficient EAL researchers feel disadvantaged in some ways compared to their native English-speaking counterparts. However, the themes that emerged from the interviews with the researchers suggest that the experience of being an EAL writer is a highly situated one, and that making generalizations about EAL writers as a group may be difficult. Perhaps the main contribution of this study is to draw attention to the role of the institutional environment.

Even among Scandinavian researchers, the international focus of the institute in this study means that their competence in English is higher than is likely to be found in other research-producing settings in Norway. Not only do publications in the topics covered by the institute exist almost exclusively in English, but the institute aims to have an international staff and thus the everyday language spoken at the institute is also primarily English. This means that although Norwegian might be the language spoken by my participants when they are at home, English dominates when they are researching and writing in their areas of expertise, as well as interacting with colleagues. For Norwegians at the 
institute in this study, English is the language of both input and output to a much greater degree than for many other Norwegian research-producing settings.

Moreover, the situated institutional environment means that researchers at the institute are likely to spend more time writing than their counterparts in the university and college sector. Because the institute sector focuses solely on research and not on teaching, the time that many other academics spend teaching and interacting with students is spent writing grant proposals or academic publications-both of which are done almost exclusively in English. This means that the participants in my study are perhaps (on average) more experienced writers than academics in other settings where teaching and service play a greater role. The attention that my participants drew to the importance of writing practice during education underscores this point.

The constant focus on English and (perhaps resulting) English language proficiency of the Norwegians at the institute means that the challenges they face in the writing process perhaps more closely resemble those of a native English speaker than the challenges described in much of the other literature on EAL writers [5,6,12]. Rather than describing problems with uptake and marginalization, the participants in my study focus on issues of nuance, voice, and struggles with the writing process that any native speaker of English would recognize-suggesting that writing in English for them does not seem to add a qualitatively different challenge so much as it exacerbates already existing challenges that all writers face.

Nevertheless, their experiences suggest that it is more difficult to feel a sense of ownership to the writing when it is in a second language. This distance from the writing was felt most keenly by those in disciplines with higher expectations for 'theoretical subtlties' [30], where writing is expected to express a unique voice. Moreover, they were quick to doubt their own voices in confrontation with a native speaker. While tentativeness and insecurity in developing an academic voice might be hallmark of all novice academics, the tendency to capitulate to the supposed expertise of a native speaker is arguably more common for EAL writers. This has implications for the ability of EAL writers to develop a sense of being an independent researcher and writer when co-authoring with a native speaker. More generally, this has implications for how identity shapes the writing experience, and adds to the existing literature on how even highly proficient EAL writers struggle with thinking of themselves as experts see, e.g., [8].

The situated context of the institute not only creates a point of departure for those at the institute to develop a proficiency in English that surpasses researchers in other settings in Norway, but it also generates certain sites of negotiation that simply do not exist for native English speakers-specifically the pressure to communicate in Norwegian to a general public. Those with English as a first language do not feel the same ethical obligation to keep Norwegian alive as an academic language or communicate to the Norwegian public.

The association of English with the academic discourse is so strong among the researchers that the observed 'truncated multilingualism' [32] might be better described as situated multilingualism: for these researchers, it is not simply a question of comfortably appropriating English for some discourses, but almost without exception, the Norwegian participants in my study reported feeling more confident in English than in Norwegian when it comes to writing academically in their areas of expertise. In other words, their proficiency in a second language on certain topics actually surpasses their proficiency in their native language.

For practitioners working with EAL researchers, this study has two main implications: the first is that it is not only the language background of the researcher that is relevant, but also their institutional environment. Supporting academic writing for publication for 'Norwegian researchers' in one institute might mean something entirely different than supporting 'Norwegian researchers' in another. The same is likely to be true for EAL writers in all countries with all language backgrounds. The institutional environment determines the value that is placed on English-language and local-language publications and the resulting pressures to publish in one language over the other; the dominant language of the relevant literature with which the researcher engages; the expectations for language in everyday 
informal exchanges related to research; and the overall amount of academic writing that is produced. Working with individual EAL writers means taking into account this institutional environment. Second, while the writing challenges faced by the participants in my study seem on the surface to be no different from those faced by any academic writer, the level of insecurity was arguably disproportionately high. Working with EAL writers means not only focusing on conventions for language and writing, but also addressing the more psychological issues such as impostor syndrome, lack of ownership to one's work, and developing an identity as an academic.

Finally, it is worth making some remarks about power. Academic literacies research draws attention not only to competing pressures and identity work, but also to unequal distributions of (geolinguistic) power. When it comes to academic publishing, power can mean the ability to participate in a discourse and be heard, or to communicate an idea in a voice that feels like your own. But for most, it means being recognized and rewarded for what you do. For researchers throughout Norway, the Norwegian bibliometric system both directly and indirectly gives primacy to publication in English, which gives the institute examined here an advantage over other social science institutes in Norway with a less international focus. The researchers can hardly be described as 'off network', not when they rank among top in their fields and the institute hosts two top-ranking (and English-language) international relations journals. In this way, the institute's researchers bear little resemblance to many of the EAL writers described in the literature. Yet the socio-political context of the institute and the international research in which it engages means that the Norwegians at the institute feel obligated to also produce output that is not rewarded or officially recognized by reaching out (usually in Norwegian) to the general public. When they compare themselves to their native-English speaking colleagues, many feel both less experienced and less competent. The differences between native English speakers and Norwegians at the institute might be small in the sense that the biggest writing challenges might be related to being a novice academic writer, but this study shows that writing in English as an additional language brings an extra dimension of difficulty to something that was already difficult to begin with-which means that 'linguistic injustice' might not be such a myth after all.

Funding: This research received no external funding.

Conflicts of Interest: The author declares no conflict of interest.

\section{References}

1. Brock-Utne, B. Is Norwegian threatened as an academic language? Int. High. Educ. 2007, 15-16.

2. López-Navarro, I.; Moreno, A.I.; Quintanilla, M.A.; Rey-Rocha, J. Why do I publish research articles in English instead of my own language? Differences in Spanish researchers' motivations across scientific domains. Scientometrics 2015, 103, 939-976. [CrossRef]

3. Flowerdew, J. Problems in writing for scholarly publication in English: The case of Hong Kong. J. Second Lang. Writ. 1999, 8, 243-264. [CrossRef]

4. Hanauer, D.I.; Englander, K. Quantifying the burden of writing research articles in a second language: Data from Mexican Scientists. Writ. Commun. 2011, 28, 403-416. [CrossRef]

5. Flowerdew, J. Scholarly writers who use English as an Additional Language: What can Goffman's "Stigma" tell us? J. Engl. Acad. Purp. 2008, 7, 77-86. [CrossRef]

6. Pérez-Llantada, C.; Plo, R.; Ferguson, G.R. "You don't say what you know, only what you can": The perceptions and practices of senior Spanish academics regarding research dissemination in English. Engl. Spec. Purp. 2011, 30, 18-30. [CrossRef]

7. Duszak, A.; Lewkowicz, J. Publishing academic texts in English: A Polish perspective. J. Engl. Acad. Purp. 2008, 7, 108-120. [CrossRef]

8. Ingvarsdóttir, H.; Arnbjörnsdótir, B. Writing English for Research and Publication Purposes (ERPP): Personal identity and professional voice. In Language Development across the Life Span: The Impact of English on Education and Work in Iceland; Arnbjörnsdótir, B., Ingvarsdóttir, H., Eds.; Springer: Cham, Switzerland, 2018; pp. 197-214. 
9. Pérez-Llantada, C. Formulaic language in L1 and L2 expert academic writing: Convergent and divergent usage. J. Engl. Acad. Purp. 2014, 14, 84-94. [CrossRef]

10. Englander, K. Transformation of the identities of nonnative English-speaking scientists as a consequence of the social construction of revision. J. Lang. Identity Educ. 2009, 8, 35-53. [CrossRef]

11. Lillis, T.; Curry, M.J. Academic Writing in a Global Context: The Politics and Practices of Publishing in English; Routledge: London, UK, 2010; p. 203.

12. Lillis, T.; Curry, M.J. The politics of English, language and uptake. AILA Rev. 2015, 28, 127-150.

13. Lillis, T.; Curry, M.J. English, scientific publishing and participation in the global knowledge economy. In English and Development: Policy, Pedagogy, and Globalization; Erling, E.J., Seargeant, P., Eds.; Multilingual Matters: Bristol, UK, 2013; pp. 220-242.

14. Casanave, C.P. The stigmatizing effect of Goffman's stigma label: A response to John Flowerdew. J. Engl. Acad. Purp. 2008, 7, 264-267. [CrossRef]

15. Kuteeva, M.; Mauranen, A. Writing for publication in mulitlingual contexts: An introduction to the special issue. J. Engl. Acad. Purp. 2014, 13, 1-4. [CrossRef]

16. Hyland, K. Academic publishing and the myth of linguistic injustice. J. Second Lang. Writ. 2016, 31, 58-69. [CrossRef]

17. Olsson, A.; Sheridan, V. A case study of Swedish Scholars' Experiences. Writ. Commun. 2012, 29 , 33-54. [CrossRef]

18. Swales, J.M. Research Genres; Cambridge University Press: Cambridge, UK, 2004.

19. Levin, S.G.; Stephan, P.E. Research productivity over the life cycle: Evidence for academic scientists. Am. Econ. Rev. 1991, 81, 114-132.

20. Kweik, M. Academic generations and academic work: Patterns of attitudes, behaviors, and research productivity of Polish academics after 1989. Stud. High. Educ. 2015, 40, 1354-1376. [CrossRef]

21. Saposnik, G.; Ovbiagele, B.; Raptis, S.; Fisher, M.; Johnston, S.C. Effect of English proficiency and research funding on acceptance of submitted articles to "Stroke" journal. Stroke 2014, 45, 1862-1868. [CrossRef]

22. Curry, M.J.; Lillis, T. Multilingual scholars and the imperative to publish in English: Negotiating interests, demands, and rewards. TESOL Q. 2004, 38, 663-688. [CrossRef]

23. Belcher, D.D. Seeking acceptance in an English-only research world. J. Second Lang. Writ. 2007, 16, 1-22. [CrossRef]

24. Bentley, P.J.; Kyvik, S. Academic work from a comparative perspective: A survey of faculty working time across 13 countries. High. Educ. 2012, 63, 529-547. [CrossRef]

25. Teodorescu, D. Correlates of factulty publication productivity: A cross-national analysis. High. Educ. 2000, 39, 201-222. [CrossRef]

26. Mamiseishvili, K.; Rosser, V.J. International citizen faculty in the United States: An examination of their productivity at research universities. Res. High. Educ. 2010, 51, 88-107. [CrossRef]

27. Lillis, T.; Curry, M.J. Professional academic writing by multilingual scholars: Interactions with literacy brokers in the production of English-medium texts. Writ. Commun. 2006, 23, 3-35. [CrossRef]

28. Bauder, H. The international mobility of academics: A labour market perspective. Int. Migr. 2015, 53, 83-96. [CrossRef]

29. Wanner, R.A.; Lewis, L.S.; Gregorio, D.I. Research productivity in academia: A comparative study of the sciences, social sciences and humanities. Sociol. Educ. 1981, 54, 238-253. [CrossRef]

30. Gnutzmann, C.; Rabe, F. "Theoretical subtleties" or "text modules"? German researchers' language demands and attitudes across disciplinary cultures. J. Engl. Acad. Purp. 2014, 13, 31-40. [CrossRef]

31. Geetz, C. Works and Lives: The Anthropologist as Author; Stanford University Press: Stanford, CA, USA, 1988.

32. Blommaert, J.; Collins, J.; Slembrouck, S. Spaces of multilingualism. Lang. Commun. 2005, 25, $197-216$. [CrossRef]

33. Street, B.V. Social Literacies: Critical Approaches to Literacy in Development, Ethnography, and Education; Longman Group Limited: Essex, UK, 1995; p. 179.

34. Lea, M.R.; Street, B.V. The "academic literacies" model: Theory and applications. Theory Into Pract. 2006, 45, 368-377. [CrossRef]

35. Barton, D.; Hamilton, M.; Ivanic, R. (Eds.) Situated Literacies: Reading and Writing in Context; Routledge: London, UK, 2000. 
36. Flower, L. The Construction of Negotiated Meaning: A Social Cognitive Theory of Writing; Southern Illinois University Press: Carbondale, IL, USA, 1994.

37. Ivanic, R. Writing and Identity: The Discoursal Construction of Identity in Academic Writing; John Benjamins Publishing Company: Amsterdam, The Netherlands, 1998; p. 373.

38. Nygaard, L.P. Publishing and perishing: An academic literacies framework for investigating research productivity. Stud. High. Educ. 2017, 42, 519-532. [CrossRef]

39. Nygaard, L.P.; Bellanova, R. Lost in quantification: Scholars and the politics of bibliometrics. In Global Academic Publishing: Policies, Perspectives and Pedagogie; Curry, M.J., Lillis, T., Eds.; Multilingual Matters: Bristol, UK, 2018.

40. Paltridge, B.; Starfield, S.; Tardy, C. Ethnographic Perspectives on Academic Writing; Oxford University Press: Oxford, UK, 2016.

41. Lillis, T. Ethnography as method, methodology, and "deep theorizing". Writ. Commun. 2008, 25, 353-388. [CrossRef]

42. Lillis, T.; Scott, M. Defining academic literacies research: Issues of epistemology, ideology and strategy. J. Appl. Linguist. 2007, 4, 5-32. [CrossRef]

43. Lillis, T. Bringing writers' voices to writing research: Talk around texts. In Why Writing Matters: Issues of Access and Identity in Writing Research and Pedagogy; Carter, A., Lillis, T., Parkin, S., Eds.; John Benjamins Publishing Co.: Amsterdam, The Netherlands, 2009; pp. 169-187.

44. Anderson, L. Publishing strategies of young, highly mobile academics: The question of language in the European context. Lang. Policy 2013, 12, 273-288. [CrossRef]

45. McGrath, L. Parallel language use in academic and outreach publication: A case study of policy and practice. J. Engl. Acad. Purp. 2014, 13, 5-16. [CrossRef]

(C) 2019 by the author. Licensee MDPI, Basel, Switzerland. This article is an open access article distributed under the terms and conditions of the Creative Commons Attribution (CC BY) license (http:/ / creativecommons.org/licenses/by/4.0/). 